\title{
RHEUMATOID ARTHRITIS
}

\author{
REVIEW
}

BY

\section{G. D. KERSLEY}

Since 1939 there has been no epoch-making discovery in relation to rheumatoid arthritis, but, as Davidson (1944) remarks, any tendency to discourage the attainment of better facilities for treatment and research, because we do not yet know the specific cause of the disease, is as ridiculous as it would be disastrous. During the war years much has, however, been written on the subject of rheumatoid arthritis and our ideas have crystallized in several directions.

\section{Aetiology}

As stated above, the cause of rheumatoid arthritis is not known, but Davidson (1945) voices British opinion in stating that " suggestive features favour the view that infections play some aetiologic role," but that most evidence points to the fact " that it is due to the abnormal immunological reaction of the host to infection " rather than the response to a specific infection. Levinthal (1939) comes to the conclusion that the essential factor is an abnormal immune body response, while both Angevine and Fraser (1942), in separate series of blood and synovial fluid cultures, find no evidence to support a specific infective aetiology. Slater (1943) assesses the case records of 388 cases and comes to the conclusion that fatigue and emotional crises are of great importance, but that the effect of heredity, the endocrine system, pregnancy, the menopause, body build, vitamins, and diet are not proven causative factors. He found that $70 \%$ of the cases were women and that the average age of onset was 40.

Pemberton (1945) discusses rheumatoid arthritis as a "mesodermatosis" and brings out the possible interrelationship between the arthritides and the arthroses. He also mentions the importance of the psychosomatic element (Halliday, 1941), and reminds us that an analysis of cases arising after the 1914-1918 war showed an exposure factor in $60 \%$, but no evidence to back up focal infection as of importance.

Selye (1944) produced a polyarthritis with, in some cases, lesions very similar to Aschoff's nodes and polyarteritis nodosa, by administering to rats desoxycorticosterone in large doses with extra sodium chloride, but this work has not yet been confirmed and the dosage used was extremely high.

Snyder (1943) found benefit in rheumatoid arthritis and ankylosing spondylitis from massive doses of vitamin D: in 32 cases the results were classified as 5, very good; 2, good; and 18, fair. The dosage used was very high, and, again, these results, so far, are unconfirmed.

Gardner (1945), following up Hench's work on jaundice and rheumatoid arthritis, found that remissions occurred in 25 out of 32 cases and lasted on an average for 42 days.

The relation of psoriasis to rheumatoid arthritis has been reviewed (Bauer, 1941) and its incidence given as $2.7 \%$ among rheumatoids and only $0.7 \%$ in controls. Characteristics are that it usually affects the nails, the bony destruction in the joints is very rapid, and either the arthritis or the psoriasis may make its appearance first.

\section{Morbid Anatomy}

Whereas, in this country, there is great scepticism over the interrelation between rheumatoid arthritis and rheumatic fever, in America the post-mortem findings in rheumatoid arthritis of cardiac lesions resembling those found in rheumatism in a high percentage of cases has revived interest in this possibility. Young and Schwedel (1944) found such lesions in 24 out of 38 cases; Bayles (1943) in 6 of 23 cases, and Rosenberg and Baggenstoss (1943) in 16 out of 30 . The interpretation of these results depends on what is considered to be pathognomonic of an Aschoff node. The same question has been raised over the subcutaneous nodules found in both syndromes; many think them of the same pathology, though those in rheumatoid arthritis are larger and come and go more slowly (Dawson, 1933), but Collins (1937) considers them to be a non-specific connective tissue reaction, which can be produced by a number of stimuli such as traumatic tenosynovitis, vitamin $C$ deficiency, and granuloma annulare. The rheumatoid arthritis nodule can, however, usually be distinguished under the microscope from that obtained from a rheumatic fever case. This view is held both by Collins (1939) and Bennett (1943). Nodules just visible to the naked eye $(0 \cdot 14-0.2 \mathrm{~mm}$. diameter) have been described in the perineurium of the peripheral nerves in 7 of 8 cases of rheumatoid arthritis examined post mortem (Leichtentritt, 1943), but in none of 100 controls. It is suggested that these lesions may be responsible for some of the neuritic pains and trophic changes, 
wasting and spasm, so frequently found in this condition. Similar nodules, some visible only under the microscope, were discovered by Freund in all of 14 muscle biopsies from rheumatoid subjects, but in none of a large number of controls.

A further paper that may well help to revolutionize our ideas on pathology in Rheumatoid Arthritis has just been published by Steiner, Freund, Leichtentritt and Maun. They confirm the nodular inflammatory re-action around many peripheral nerves and also some of the small arteries to the muscles; they have now found the perineuritic lesions in 8 out of 10 cases at post-mortem examination. Moreover, they describe in detail " polymyositic nodules" found in all of nine cases examined, seven by biopsy and two at post-mortem, and in 9 out of 10 small samples taken from various muscles. In view of this, biopsy of muscle may become an important diagnostic criterion in atypical cases. The authors consider the primary tissue change to be in the endo- and peri-mysium with secondary degeneration in the muscle fibres. Degeneration of nervous tissue was not observed. The nodules in the connective tissue between the fibres varied in size from small collections of cells, seen only under the microscope, to those easily visible to the naked eye in sections of tissue. They were round, oval or spindle shaped and sometimes tapered off, infiltrating the planes of the endomysium. They consisted of collections of lymphocytes and plasma cells, with also a few mast cells, while around the periphery of the larger nodules were collections of epitheloid cells. An increase in collagenous connective tissue characterized by its lack of reticular network was also found. These changes were present in both early and late cases-onset 4 months to 19 years before examination-in apparently " burnt out " cases and in those treated or untreated with gold, but in none of 196 control specimens. In addition to these characteristic changes, in many there were signs of muscle degeneration, commencing with an abnormal staining re-action, "invasion " of the contractile substance of fibres by nuclei and vacuolization, irregularity of contour, loss of striation and finally shrinkage of the fibres themselves. This work demonstrates the wide-spread nature of the pathology of Rheumatoid Arthritis and histological evidence of activity during clinical quiescence. The lesions seen were quite distinct from any described in fibrositis and appear to be specific to Rheumatoid Arthritis.

Felty's syndrome of enlargement of the spleen, leucopenia, and pigmentation was not supported as a distinct entity after review of 15 cases by Hatch (1945), and the operation of splenectomy advised by Steinberg (1942) was discredited by this writer. Bach (1940) previously had reported improvement in two of three cases thus operated on.

\section{Treatment}

The use both of sulphonamides, except at the time of removal of septic foci, and penicillin (Boland et al., 1944 and 1945) has been most disappointing. Likewise the bulk of the medical profession, both here and in the U.S.A., is becoming very sceptical of the value of vaccines except in specially selected cases.

The value of rest and general treatment of the patient as a whole is becoming better recognized in all critical reviews.

The correction of deformity by the use of serial plasters as advocated originally by Swaim, Kindersley (1935), and others, is now accepted both here and in the U.S.A. as the best method, capsulotomy also being employed if necessary (Freyberg, 1942; Kuhns, 1943).

Ideas on the value and dosage of aurotherapy have been modified a great deal. While for some time it has been much used for selected cases in this country, it has been regarded with suspicion, until recently, in America. Even in 1941 Bauer stated that of 30 cases of rheumatoid arthritis only 4 were improved following its administration. Comroe (1945), however, sums up the present American view, supported by all observers in this country, that gold is of definite value in active cases of the disease that are failing to react to rest and other rational, general and local treatment. Fraser (1945), working with a grant from the Empire Rheumatism Council, carried out a carefully controlled investigation on 103 cases. Fifty-seven received myocrisin (sodium aurothiomalate) and 46 a control injection.

Eighty-two per cent. of those receiving gold were improved and only $45 \%$ of the controls. The dosage used was on an average: $0.01 \mathrm{gm} . \times 1$, 0.02 gm. $\times 2,0.05$ gm. $\times 1,0.1$ gm. $\times 9$. Total: 1 gramme. Where necessary, a second course of injections was given after a lapse of three months. Slight toxic reactions occurred in $75 \%$, but in none were they alarming. In 7 cases the treatment had, however, to be abandoned. The reactions were: general, 4; skin, 37 (2 severe); albuminuria, 30 (5 severe); stomatitis, 7; colitis, 1; agranulocytosis, none. Comroe advises a still smaller dosage: $0.005 \mathrm{gm} . \times 4,0.01 \mathrm{gm} . \times 2,0.025 \mathrm{gm}$ $\times 24$. Total: 0.5 gramme; the course to be repeated in eight weeks if there was benefit from the first series. By using this very small dosage he considers that the results are equally good and that less toxic reactions are produced. He finds reduction in pain and swelling and increase in appetite and weight usually begins in one to three months after starting the injections. He points out that, if one injection of $0.1 \mathrm{gm}$. is given, only $20 \%$ is excreted in a week and that gold may be found in the urine ten months after completion of a course, the liver, kidney, spleen, and skin, in particular, acting as depots. Goldie (1939) carefully correlated the sedimentation rate, during aurotherapy, in 400 cases. He found that the initial sedimentation rate had no bearing on the prognosis, but the clinical improvement and fall in the sedimentation rate during treatment usually coincided. If there was no fall in the sedimentation rate during the first course a second was also unlikely to produce one 
With regard to the best preparation of gold to be used, Sabin (1941) found that the effectiveness of the gold salt varied with its gold content. Comroe advises the crystalline salts rather than the colloidal ones as being more effective, though more toxic, and Freyberg (1942) advocates calcium aurothiomalate (auro-calcium) as slightly less toxic than the sodium salt (myocrisin).

To sum up-aurotherapy has come to stay till something better is discovered. Very small dosage is needed, and the crystalline organic calcium salt probably is the least toxic of the really effective preparations available.

\section{REFERENCES}

Angevine, D. M. et al. (1942). Ann. Rheum. Dis., 3, 101. Bach, F., and Savage, O. (1940). Ibid., 2, 47. Bauer, w. et al (1941). Trans. Ass. Amer. Phys., 56, 349. Bayles, T. B. (1943). Amer. J. med. Sc., 205, 42

Bennett, G. A. (1943). Ann. intern. Med., 19, 111.

Boland, E. W., Headley, N. E., and Hench, P. S. (1944). Proc. Mayo Clin., 19, 505. (1945). Ann. Rheum. Dis., 4, 76.
Collins, D. H. (1937). J. Path. Bact., 35, 97. (1939). Ann. Rheum. Dis., $1,38$.

Comroe, B. I. (1945). J. Amer. Ass., 128, 848.

Copeman, W. S. C. (1936). Rep. Rheum. Dis. London, $2,24$.

Davidson, L. S. P. (1943), Glasgow Med. Jour., 140.

Dawson, M. H. (1933). J. exp. Med., 57, 845.

Fraser, T. N. (1945). Ann. Rheum. Dis., 4, 71. (1942). Ibid., 3, 181 Freund, H. A., et al. (1942). Amer. J. Path., 18, 865. (1945).

Freyberg, R. H.. et al. (1942). Proc. Mayo Clin., 17, 534. (1942). Ann. Rheum. Dis. 3, 77.

Gardner, F., et al. (1945). Brit. Med. J., 2, 677.

Goldie, W. (1939). Ann. Rheum. Dis. 1, 319.

Halliday, J. L. (1941). Ann. inten. Med., 15, 666

Halliday, J. L. (1941). Ann. inten.
Hatch, F. N. (1945).
Ibid., 23, 201.

Hatch, F. N. (1945). Ibid., 23, 201. 35. London (1938). A survey of Chronic Rheumatic Diseases, 35. London

Kindersley, C. E. (1935). Proc. roy. Soc. Med., 29, 237.

Kuhns, J. G. (1943). Ann. inten. Med., 10, 131.

Leichtentritt, B. (1943). Ibid., 19, 116.

Levinthal, W. (1939). Ann. Rheum. Dis., 1, 67.

Pemberton, R. (1945). Amer. J. Med. Sci., 209, 364

Review of Amer. and Eng. Literature. 1940. Hench, P. S. et al. (1941). Ann. inten. Med., 15, 1002.

Rosenberg, E. F., Baggenstoss, A. H., Hench, P. S. (1943). Ibid., $19,116$.

Sabin, A. B. (1941) Bact. Rev., 5, 1.

Selye, H., et al. (1944). J. Amer. med. Ass., 124, 201.

Slater, J. G. (1942). Ann. Rheum. Dis., 3, i95.

Snyder, R. G. et al. (1943). Ann. inten. Med., 19, 125.

Snyder, R. G., et al. (1943). Ann. Inten. Med., 19, 125.

Steiner, G., Freund, H. A., Leichtentritt, B., and Maun, M. E. Amer. J. Path., 1946, 22, 103.

Young, D., and Schwedel, J. B. (1944). Amer. Heart J., 28, 1 